\title{
POTENTIALS FOR SUNFLOWER CULTIVATION FOR FUEL PRODUCTION IN SOUTHERN ITALY
}

Flagella, Z. , Di Caterina, R., Monteleone, M., Giuzio, L., Pompa, M., Tarantino, E., Rotunno, T.

Department of Agro-Environmental Science, Chemistry and Plant Protection, Via Napoli, 25 - 71100 Foggia, Italy and

Bioagromed Research Centre, Via Napoli, 52 -71100 Foggia, Italy

Received: October 15, 2006 Accepted: December 05, 2006

SUMMARY

The use of fuels derived from vegetable oils represents a potential opportunity to meet EU Commission guidelines promoting renewable energy utilization. This is particularly true for Mediterranean countries where farmers are well familiarized with oil crops. Sunflower is one of the most adapted crops to dry conditions typical of Mediterranean environments. The oleic acid content in sunflower oil seems to be a suitable character for biofuel production with regard to fuel oxidative stability. For the same reason, the high oleic varieties are considered particularly promising. In this study the effect of climatic conditions and agronomic practices on oleic acid content of sunflower seeds is investigated with respect to the Southern Italy regions. Effects of high temperature, water deficit, irrigation water quality, sowing time and genotype on oil yield and quality are evaluated. Finally, the potential of sunflower cultivation for biofuel production in the light of the recent European agricultural policy is discussed.

Key words: sunflower, oil, biofuel, Southern Italy, fatty acid

\section{INTRODUCTION}

A new, interesting scenario seems to appear with respect to sunflower in Southern Italy. Subsequent to the impulse produced by the application of the PAC reform (subsidies decoupled from production and single payment scheme), signals of a significant increase in sunflower cultivation are recorded. This new condition is demonstrated by the doubling of the surfaces allocated to the crop during the 2005-06 period, after several years of progressive reduction (Frascarelli, 2006). According to the new PAC reform package (Campagna and Rapparini, 2006), this situation seems to be determined by a loss of economic competitiveness of the alternative crops to sunflower, i.e., the spring sowing crops such as sugar beet and tomato, as

* Corresponding author: e-mail: z.flagella@unifg.it 
well as by a reduced interest in durum wheat as a winter crop. However, it is also suitable to mark the promising potentialities of this oleaginous crop; besides its traditional food destination, progressively growing is the use of oil as an energy source (Bona et al., 1999). Such a destination allows to consider establishing an industrial chain as interesting as that of alimentary oils.

Particularly pressing appears the request to increase the technical efficiency of the cropping pattern and to genetically improve the set of cultivars' availability, in order to reach the double purpose, to reduce cultivation costs and to increase the crop productive potentiality and stability.

In comparison with the regions of Central Italy, traditionally suitable for sunflower cultivation in rainfed conditions, Southern Italy regions experience serious constraints of reduced water availability and high temperature regime due to a hot, sub-arid climate.

The aim of the paper was to review the available literature concerning the effects of climatic conditions and the influence of agronomic practices typically applied in sunflower cultivation in Southern Italy on oil quality, with particular reference to the oleic acid enrichment. This character indeed seems to be suitable to reinforce the biodiesel oxidation stability (Bondioli and Folegatti, 1996; da Silva et al., 2003). Furthermore, this paper reports also the main political and economic European initiatives devoted to promoting biofuel production and marketing, which significantly increase the interest oin sunflower cultivation as a non food crop.

\section{RESULTS AND DISCUSSION}

\section{Genetic and environmental effects on sunflower oil quality}

Although sunflower yield performances and oil fatty acid composition mostly depend on genetic potential, environmental factors like climatic conditions as well as agronomic techniques can significantly affect both achene yield and oil quality.

\section{Effect of genotype}

With regard to oil fatty acid composition, besides the standard varieties with a high linoleic acid content (above 60\%), high oleic cultivars were progressively available starting from the 1980's. Nowadays, the high oleic sunflower hybrids show yield performances similar to the standard ones and their oleic acid content is stable and very high, reaching $85-90 \%$ of the total fatty acid composition (Monotti et al., 2003). This is considered a significant result, especially with respect to industrial uses such as biodiesel production. In fact, a high oleic acid content ensures a better oxidative stability of sunflower oil (Bondioli and Falegatti, 1996). 


\section{Effect of temperature}

Temperature is the main environmental factor affecting sunflower oil quality, especially during grain filling (Trèmolières et al., 1982). In vivo experiments with developing sunflower seeds demonstrated that oleate desaturase activity was stimulated by low temperature, repressed by high temperature and rapidly restored upon returning to seed exposure to low temperature (Sarmiento et al., 1998). Further studies (Rondanini et al., 2003) confirmed the influence of temperature on fatty acid composition both in standard and high oleic sunflower hybrids. A larger variation in oleic acid content was observed in standard hybrids (Izquierdo et al., 2002).

\section{Effect of sowing date}

In Southern Italy, sunflower is a typical spring sowing crop, usually sown between March and April. Most of the crop cycle takes place in summer when evapotranspiration is high and rainfall is scarce and often inadequate to satisfy crop water requirement. In these conditions, early sowing can help the crop to benefit from late winter rainfall and watering is worked out only as supplementary irrigation, to support yield.

Sowing date may influence fatty acid composition. In particular, Cilardi et al. (1990) evaluated the effect of sowing date on sunflower grown as a catch crop; they observed a decrease in oleic acid concentration and an increase in linoleic acid in standard genotypes from June 10 to July 10 sowings. Anastasi et al. (2000) evaluated the effect of a shift from autumn to summer sowing time on fatty acid pattern, both in standard and high oleic hybrids; the highest oleic acid content was reached in spring sowing, while the lowest amount was recorded with autumn sowing. Flagella et al. (2002) evaluated the effect of two spring sowing dates: end of March and mid-April; they found a decrease in oleic acid and a considerable increase in linoleic acid in the earlier sowing date, both in standard and high oleic hybrids (Figure 1). Diverse planting dates caused flowering and seed development to occur in periods with different air temperatures. Consequently, the highest oleic acid content was obtained when the mean temperature was higher during grain filling. This effect may be probably due to the oleate desaturase inhibition at high temperatures.

\section{Influence of water regime}

With respect to sunflower grown in Southern Italy, well known are the positive effects of irrigation on yield parameters; differently, contrasting results were obtained with regard to the effect of irrigation on oil fatty acid composition. Leuzzi et al. (1993) found no effect of water stress on fatty acid composition in a conventional sunflower hybrid grown in Sicily. Instead, Flagella et al. (2002) found an increase in linoleic acid content and a parallel decrease in oleic acid under irrigation (Figure 1). This result is in agreement with Baldini et al. (2002) who showed 
that the oleic acid percentage in sunflower oil increased stopping irrigation from flowering to physiological maturity as compared with water regimes based on the full ET crop restoration. Conversely, other authors (Santonoceto et al., 2003) observed that oleic acid content was higher under irrigation than under rainfed conditions.

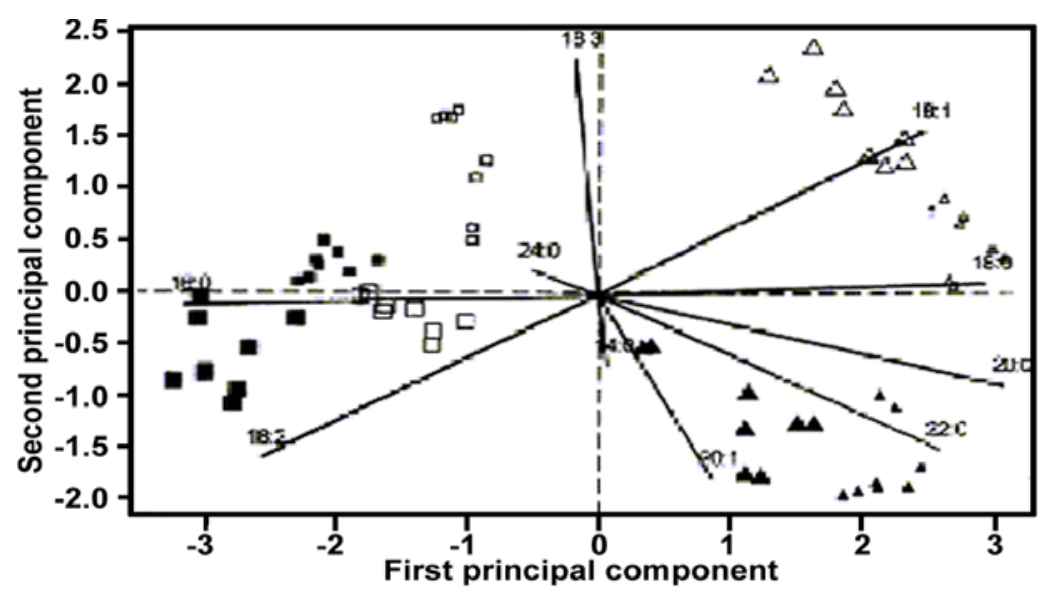

Figure 1: Principal Component Analysis (PCA) relative to the fatty acid composition of two high oleic sunflower hybrids grown under two water regimes and two sowing dates. Vyp70 irrigated: $\mathbf{\square}$; Vyp70 non irrigated: $\square$; Platon, irrigated : $\mathbf{\Delta}$; Platon, non irrigated: $\triangle$. Wide and small symbols are relative to the early and the standard sowing date, respectively. Modified by Flagella et al. (2002).

Water quality can also affect sunflower yield. Several studies showed a progressive reduction in achene yield and seed oil content with an increasing salinity level of irrigation water. These results confirmed that sunflower is a moderately tolerant crop to salt stress, in accordance with Maas \& Hoffman model (1977). Flagella et al. (2004) observed that salt stress significantly affected oil fatty acid composition; with respect to high oleic sunflower hybrid, oleic acid showed an increase from 82.8 to $86.8 \%$ compared with the control (tap water) in the highest salinity treatment ( $\mathrm{ECw}$ equal to $12 \mathrm{dS} \mathrm{m}^{-1}$ ).

\section{The European policy on biofuels}

The availability of renewable energy sources is a key factor to achieving sustainable development and protecting the environment. In this regard, the EU policy and legislation operate through different converging pathways: promoting industrial improvement, supporting financial enterprises, regulating the Common Agricultural Policy (CAP) and the environmental low.

Liquid biofuels are the only direct substitute for oil in transport and, for this reason, have high political priority. Directive 2003/30/CE of the European Parliament and the Council is aimed at promoting the use of renewable fuels in order to replace diesel oil and gasoline (petrol) for transportation, with the goal of diversify- 
ing the European energy supply, reducing the reliance on imported energy, contributing to the reduction of greenhouse gases emissions and climate changes (Kyoto Protocol targets) and enforcing the environmental safety. As a matter of fact, a target value of $2 \%$ of the market share for biofuels was set in 2005 in order to reach the $5.75 \%$ in 2010 . The 2005 reference value, however, has not been achieved and great efforts still have to be made; these values, furthermore, have been reduced by the Italian government in the application of the Directive (D.Lgs. 128/05) to $1 \%$ and $2.5 \%$, respectively. Member States are using two main tools for implementing the Biofuels Directive: tax exemption and biofuel obligations. Fiscal policy can promote biofuels being reduced or completely exempt from taxes (tax exemption). In this respect, the Italian government has adopted a quota-based approach, limiting the quantity of biofuel qualified for tax exemption and setting up a process of identifying the firms that will benefit from it. Actually, in Italy, a six-year plan (2005-2010) of full tax exemption was restricted to the amounts from 300.000 to 200.000 tons of biofuel; this decreasing amount is justified in order to prevent the use of cheap oil imported from other countries. Another possibility is that tax exemption is applied only to biofuels obtained from national cultivations (domestic production) complying to minimum sustainability standards and following supply-chain agreement. The other strategy to promote the renewable energy is through biofuels obligations: fuel supply companies are requested to incorporate a given percentage of biofuel in the non renewable fuel they place on the national market. Starting from the 1 July 2006, the Italian fuel producers are compelled to incorporate $1 \%$ of biofuel in the total fuel sold; this share will be increased by $1 \%$ each year in order to reach the value of $5 \%$ in 2010 .

Other important part of the supporting policy, at the national level, concerns special agreements along the supply chain and agro-energetic contract plans with the agricultural organizations; as long as the price of sunflower seed proposed by biofuel firms ( 180 Euro/t) does not fit the farmers' request (at least 208-210 Euro/t) it will be difficult to observe a significant increase in the national surfaces cropped with sunflower. The same economic problem originates from the cost of sunflower oil; it is difficult to believe in a development of a biofuel supply chain as long as the sunflower oil is estimated at more than 550 Euro/t in comparison with about 400 Euro/t of a raw palm oil that is currently imported in our country.

The overall costs pertaining to biodiesel production from sunflower can be estimated to about 0.537 Euro/l, which is still higher compared with mineral diesel (0.507 Euro/1); this gap, however, is not insuperable considering that the oil prices trend is dramatically increasing.

Important resolutions come from the application of the CAP reform. This reform, above other things, introduced a special aid to "energy crops" and maintained the possibility of using mandatory "set-aside" land for growing non-food crops (including energy crops). At present, the biomass credit currently amounts to 
45 Euro/ha on condition to draw up a supplying contract with an authorized transformer.

Beside biodiesel, electrical energy production could be an interesting solution, also starting from sunflower seed. From the farmer point of view, a very attractive decision, just taken at the national level, is that of considering the production of electrical energy (as well as heating and photovoltaic power) as a productive activity strictly connected to that of agriculture, on condition to employ biomass derived from their own farm. It means that no additional taxes are imposed on agricultural profits derived from the sale of renewable energy. Renewable energy producers (farmers as well) can also offer the so called "Green Certificates" requested by the conventional energy producers; this is an important part of the promoting system on biofuels that will allow an additional income to be accounted (108.92 Euro/ MWh).

\section{CONCLUSIONS}

Sunflower cultivation for biodiesel production seems to be suitable under the typical environmental conditions of Southern Italy. A relative enrichment in oleic acid content may be obtained under water deficit and salt stress conditions as well as under later sowing times. The potential expansion of sunflower cultivation for biofuel production in Southern Italy is encouraging, also in the light of the recent reform of the European Community Agricultural Policy (CAP).

In this regard, two different options are expected: a) the production of raw material to supply biofuel firms in a global and competitive market so that sunflower seed can be considered in the same way as other agricultural commodities, such as sugar beet, and likewise subjected to general agreement on price and quantities; b) the local setup of a "short" seed and oil supply chain in order to directly produce energy (heat power, cold and/or electricity) at the farm level (agricultural unions and co-operative societies); in this second choice, energy generation can derive directly from the oil combustion without the necessity to go through biofuel production.

These two options pertain to radically different scenarios but are not mutually exclusive; the first one is tailored more for industrial needs while the second more for the needs of the farmers.

\section{REFERENCES}

Anastasi, U., Cammarata, M., and Abbate, V., 2000. Yield potential and oil quality of sunflower (oleic and standard) grown between autumn and summer. Italian Journal of Agronomy 4: 23-36.

Baldini, M., Giovanardi, R., Tahmasebi-Enferadi, S., Vannozzi, G.P., 2002. Effects of water regime on fatty acid accumulation and final fatty acid composition in the oil of standard and high oleic sunflower hybrids. Italian Journal of Agronomy 6: 119-126. 
Bona, S. Mosca, G., and Vamerali, T., 1999. Oil crops for biodiesel production in Italy. Renewable Energy 16: pp. 1053-1056.

Bondioli, P., Folegatti, L., 1996. Evaluating the oxidation stability of biodiesel. An experimental contribution. La Rivista Italiana Delle Sostanze Grasse, Vol. LXXIII - August, pp. 349-353.

Campagna, G., Rapparini, G., 2006. Olio combustibile nel futuro del girasole. L'Informatore Agrario Speciale Girasole 10: 41-42.

Cilardi, A.M., Ferri, D., Lanza, F., Losavio, N. and Santamaria, P., 1990. Effetti dell'epoca di semina e degli ibridi su resa quanti-qualitativa e contenuto in acidi oleico e linoleico nell'olio del girasole (Helianthus annuus L.) in secondo raccolto. Rivista di Agronomia 24(2/3): 250-256.

da Silva Neto, F., Prata Salgano, A., Teixeira Rocha, J., 2003. Technical feasibility assessment of oleic sunflower methyl ester utilisation in Diesel bus engines. Energy conversion and Management 44: 2857-2878

Del Pino, A.M., Monotti, M., Pirani, V., Salera, E., Bianchi, A.A., Bressan, M., Capitanio, R., Conti, D., Cardone, A.M., Pino, S., Talluri, P., Tanzi, F., 1996. Varietà di girasole "alto oleico" saggiate in diversi ambienti dell' Italia centrale e settentrionale. L' Informatore Agrario 52(6): 55-64.

Flagella, Z., Giuliani, M.M., Rotunno, T., Di Caterina, R., De Caro, A., 2004. Effect of saline water on oil yield and quality of a high oleic sunflower (Helianthus annuus L.) hybrid. European Journal of Agronomy 21(2): 267-272.

Flagella, Z., Rotunno, T., Tarantino E., Di Caterina, R., De Caro, A., 2002. Changes in seed yield and oil fatty acid composition of high oleic sunflower (Helianthus annuus L.) hybrids in relation to the sowing date and water regime. European Journal of Agronomy 17(3): 221-230.

Frascarelli, A., 2006. Il 2006 è l' anno della ripresa per il girasole. L'Informatore Agrario Speciale Girasole 10: 29-32.

Izquierdo, N., Aguirrezàbal, L., Andrade, F., and Pereyra, V., 2002. Night temperature affects fatty acid composition in sunflower oil depending on the hybrid and phenological stage. Field Crops Reserarch, 77(2): 115-126.

Leuzzi, U., Giuffrè, A.M., Mincione, B., D’ Andria, R., 1993. Sulla composizione lipidica di semi di girasole (Helianthus annuus L.) coltivato in condizioni di stress idrico. La Rivista Italiana Delle Sostanze Grasse, Vol. LXX - May, pp. 237-242.

Maas, E.V., and Hoffman, G.J., 1977. Crop salt tolerance: current assessment. J. Irrig. Drain. Div. Am. Soc. Civ. Eng. 103: 115-134.

Monotti, M., Laureti, D., Conti, D., Pieri, S., Ridoni, G., Del Pino, A.M., 2003. Nuove varietà alto-oleico di girasole. L'informatore Agrario, LIX(11): 43-47.

Robertson, J.A., Chapman, G.W., and Wilson, R.L., 1978. Relation of days after flowering to chemical composition and physiological maturity of sunflower seed. JAOCS 55: 266-269.

Rondanini, D., Savin, R., and Hall, A.J., 2003. Dynamics of fruit growth and oil quality of sunflower (Helianthus annuus L.) exposed to brief intervals of high temperature during grain filling. Field Crops Research 83: 79-90.

Santonoceto, C., Anastasi, U., Riggi, E., and Abbate, V., 2003. Accumulation dynamics of dry matter, oil, major fatty acids in sunflower seeds in relation to genotype and water regime. Italian Journal of Agronomy 7(1): 3-14.

Sarmiento, C., Garcè, F., Mancha , M., 1998. Oleate desaturation and acyl turnover in sunflower (Helianthus annuus L.) seed lipids during rapid temperature adaptation. Planta 205: 595-600.

Trèmolières, A., Dubacq, J.P., Drapier, D., 1982. Unsaturated fatty acids in maturing seeds of sunflower and rape: regulation by temperature and light intensity. Phytochemistry 21 : pp. $1-45$.

\section{POTENCIALES DEL CULTIVO DE GIRASOL PARA LA PRODUCCIÓN DE COMBUSTIBLE EN ITALIA DEL SUR} RESUMEN

La utilización del combustible obtenido del aceite vegetal es la oportunidad de cumplir los requerimientos de la Comisión de UE de utilización de los 
tipos de energía reciclable. Esto se refiere especialmente a los países mediterráneos, en los cuales los productores agrícolas son bien conocidos por cultivos oleaginosos. El girasol es el cultivo sumamente adaptado a las condiciones secas, típicas de la región mediterránea. Parece que el contenido de ácido oleico en el aceite de girasol corresponde para la producción de biocombustible en cuanto a estabilidad oxidativa del combustible. Por la misma razón, las variedades alto oleicas se consideran sumamente oportunas. En este trabajo fue investigada la influencia de las condiciones climáticas y de las medidas agrotécnicas en el contenido de ácido oleico en la semilla de girasol cultivado en diferentes partes de Italia del Sur. Fue investigada la influencia de alta temperatura, falta de humedad, calidad de agua de riego, el tiempo de siembra y el genotipo en el rendimiento y calidad de aceite. Al final se consideran las posibilidades de cultivo de girasol para la producción de biocombustible en luz de recientemente promocionada política agrícola de la UE.

\title{
POTENTIELS DE LA CULTURE DU TOURNESOL POUR LA PRODUCTION DE CARBURANT EN ITALIE DU SUD
}

\author{
RÉSUMÉ
}

L'utilisation de carburants obtenus à partir d'huiles végétales est une occasion de répondre aux exigences de la commission de l'Union européenne pour l'obtention de sources d'énergie renouvelables. Ceci concerne particulièrement les pays méditerranéens où les producteurs agricoles sont bien connus pour leurs cultures huilières. Le tournesol est l'une des cultures les mieux adaptées aux conditions arides des régions méditerranéennes. Relativement à la stabilité oxydable du carburant, il semble que le contenu d'acide oléique de l'huile de tournesol convienne à la production de biocarburant. Pour cette raison, les espèces à haute teneur oléique sont considérées comme particulièrement prometteuses. Dans cet article, l'effet des conditions climatiques et des mesures agrotechniques sur le contenu d'acide oléique dans l'akène du tournesol cultivé dans différentes parties de l'Italie du Sud est analysé. Les effets des températures élevées, du manque d'humidité, de la qualité de l'eau d'irrigation, de la période des semailles et du géotype sur le rendement en huile et sur la qualité sont évalués. Enfin, on examine les possibilités de cultiver le tournesol pour la production de biocarburant à la lumière de la nouvelle politique agricole de l'union européenne. 